\title{
The role of systemic chemotherapy and multidisciplinary management in improving the overall survival of patients with metastatic squamous cell carcinoma of the anal canal
}

\author{
Cathy Eng ${ }^{1}$, George J. Chang ${ }^{2}$, Y. Nancy You ${ }^{2}$, Prajnan Das ${ }^{3}$, Miguel \\ Rodriguez-Bigas ${ }^{2}$, Yan Xing ${ }^{2}$, Jean-Nicolas Vauthey ${ }^{2}$, Jane E. Rogers ${ }^{4}$, Aki Ohinata ${ }^{1}$, \\ Priyanka Pathak ${ }^{1}$, Salil Sethi ${ }^{1}$, Jonathan K. Phillips ${ }^{1}$, Christopher H. Crane ${ }^{3}$, \\ Robert A. Wolff ${ }^{1}$ \\ ${ }^{1}$ Department of Gastrointestinal Medical Oncology, The University of Texas M.D. Anderson Cancer Center, Houston, TX 77030 \\ ${ }^{2}$ Department of Surgical Oncology, The University of Texas M.D. Anderson Cancer Center, Houston, TX 77030 \\ ${ }^{3}$ Department of Radiation Oncology, The University of Texas M.D. Anderson Cancer Center, Houston, TX 77030 \\ ${ }^{4}$ Division of Pharmacy, The University of Texas M.D. Anderson Cancer Center, Houston, TX 77030
}

Correspondence to:

Cathy Eng, e-mail: ceng@mdanderson.org

Received: October 01, $2014 \quad$ Accepted: October 02, 2014

Published: November 14, 2014

\section{ABSTRACT}

Metastatic squamous cell carcinoma (SCCA) of the anal canal is a rare malignancy for which no standard treatment algorithm exists. To determine the best approach, all patients diagnosed with metastatic SCCA of the anal canal treated at a single institution were evaluated for choice of chemotherapy and treatment outcome. A retrospective study from January 2000 to May 2012 was conducted. Electronic medical records were reviewed for diagnosis of metastatic SCCA of the anal canal. All patients were treatment naïve for metastatic disease and completed all radiographic imaging at our institution. The purpose of this study was to evaluate outcomes among patients who received systemic chemotherapy and if appropriate were referred for multidisciplinary intervention (e.g., surgery, radiofrequency ablation, etc.). Seventy-seven patients fulfilled eligibility criteria. Forty-two patients $(55 \%)$ received 5-fluorouracil (5-FU) + cisplatin (PF); 24 patients $(31 \%)$ received carboplatin + paclitaxel (CP); 11 patients (14\%) received an alternative regimen. After a median follow-up of $\mathbf{4 2}$ months, the median progression-free survival (PFS) for all patients was 7 months; the median overall survival (OS) was 22 months. Thirty-three patients $(43 \%)$ underwent multidisciplinary management for metastatic disease resulting in a median PFS of 16 months (95\% CI: 9.2 -22.8) and median OS of 53 months (95\% CI: $28 \cdot 3-77 \cdot 6)$. Systemic chemotherapy provides durable survival for patients with surgically unresectable metastatic SCCA of the anal canal. Multidisciplinary management for select patients with metastatic disease effectively improves survival and should be considered whenever possible.

\section{NOVELTY AND IMPACT STATEMENT}

Currently very little peer-reviewed literature exists regarding treatment of patients with metastatic squamous cell carcinoma of the anal canal. The purpose of this study, which is presently the largest of its kind, was to evaluate treatment outcomes among patients receiving multidisciplinary therapy and to evaluate the benefit of systemic chemotherapy as a treatment option which is being validated in the InterAACT trial. Our findings indicate that multidisciplinary management may provide an improvement in overall survival.

\section{INTRODUCTION}

Carcinoma of the anal canal is a rare malignancy, representing only $2 \%$ of all digestive system cancers in 2014. Yet, the incidence of anal cancer continues 
to rise in the United States by 2\% per year. Often considered a malignancy only associated with chronically immunosuppressed conditions, such as human immunodeficiency virus (HIV/AIDS) infection or transplant immunosuppression, it is commonly under recognized in non-immunosuppressed individuals. An estimated 7,210 new cases of anal carcinoma will be diagnosed in the United States, resulting in 950 deaths in 2014 [1]. Greater than $90 \%$ of the cases of carcinoma of the anal canal will be of squamous cell carcinoma (SCCA) origin. Other rare types of anal cancers include melanoma, adenocarcinoma, and neuroendocrine tumors. For the purpose of our analysis, we will only be discussing the more common SCCA of the anal canal.

The majority of patients with SCCA of the anal canal present with locally advanced disease but can be treated effectively with concurrent chemoradiation therapy reserving abdominal perineal resection (APR) only for surgical salvage therapy $[2,3]$. Current standard treatment approaches for these patients include a definitive approach of concurrent chemoradiation consisting of 5-fluorouracil $(5-\mathrm{FU})+$ mitomycin $\mathrm{C}$ or $5-\mathrm{FU}+$ cisplatin. The adoption of this therapeutic approach for locally advanced SCCA of the anal canal has led to a 5 -year overall survival ranging from $61 \%-85 \%$ [4-6, 11-13]. Yet, for those patients with recurrent locally advanced disease not amenable to APR or with distant metastatic disease, a median overall survival (OS) of only 8-12 months has been reported based in small case studies [7-10].

Extrapelvic metastases are diagnosed in only $5 \%$ of patients at the time of initial diagnosis, with metastatic disease occurring in $10 \%-20 \%$ of patients following treatment for locally advanced disease. Locally recurrent pelvic disease or distant disease can contribute significantly to patient morbidity and mortality as a result of local tumor effects such as pain, sacral involvement, symptomatic bulky necrotic lymphadenopathy, and destructive anal canal involvement.

Due to the low incidence of anal carcinoma and the rarity of the development of metastatic disease, there have been no completed prospective clinical trials exclusively for metastatic anal carcinoma. On the basis of anecdotal case reports and small retrospective case series [8-10, $14-16,18-21]$, the general management of this disease in the metastatic setting has classically consisted of systemic chemotherapy. Yet, no chemotherapy treatment paradigm has been clearly established. Little published data exists other than small case studies or case series (Table 1), with minimal information regarding optimal management due to the limited sample size. Furthermore, prior

Table 1: Prior Case Reports/Cohorts in Metastatic SCCA of the Anal Canal

\begin{tabular}{|c|c|c|c|c|c|}
\hline Author & $\mathbf{N}$ & Agents & ORR & $\begin{array}{l}\text { Med PFS } \\
\text { (months) }\end{array}$ & $\begin{array}{l}\text { Med OS } \\
\text { (months) }\end{array}$ \\
\hline Wilking et al. ${ }^{18}$ & 15 & $\begin{array}{l}\text { Vincristine, Bleomycin, and } \\
\text { High-dose Methotrexate }\end{array}$ & $25 \%$ & $2 \mathrm{M}$ & NR \\
\hline Ajani et al. ${ }^{19}$ & 3 & 5-FU + Cisplatin & NA & $17 \mathrm{M}(2$ of 3$)$ & NA \\
\hline Faivre et al. ${ }^{20}$ & 18 & 5-FU + Cisplatin & $\begin{array}{l}65 \% \\
(\mathrm{CR}=15 \%)\end{array}$ & $4 \mathrm{M}$ & NA \\
\hline Hainsworth et al. ${ }^{15}$ & $\begin{array}{l}60 \text { ( } 4 \text { with squamous } \\
\text { cell carcinoma of the } \\
\text { anal cancer) }\end{array}$ & $\begin{array}{l}\text { Docetaxel, Cisplatin, and } \\
5-\mathrm{FU} \\
(\max =4 \text { cycles })\end{array}$ & $\begin{array}{l}65 \% \\
(\mathrm{CR}=25 \%)\end{array}$ & $26 \mathrm{M}$ & NR \\
\hline Jhawer et al. ${ }^{9}$ & 20 & $\begin{array}{l}\text { Mitomycin C, Adriamycin, } \\
\text { Cisplatin, and Bleomycin- } \\
\text { CCNU }\end{array}$ & $12-20(60 \%)$ & $8 \mathrm{M}$ & $15 \mathrm{M}$ \\
\hline Alcindor $^{8}$ & 5 & Paclitaxel ( $1^{\text {st }}$ and $2^{\text {nd }}$ line $)$ & $60 \%$ & Range: $3-8 \mathrm{M}$ & $\begin{array}{l}\text { Range: } \\
4-20 \mathrm{M}\end{array}$ \\
\hline Abbas et al. ${ }^{10}$ & 7 & Paclitaxel (2 $2^{\text {nd }}$ line $)$ & $57 \%$ & Range: $2-8 \mathrm{M}$ & $\begin{array}{l}\text { Range: } \\
5-14 \mathrm{M}\end{array}$ \\
\hline Kim et al..$^{21}$ & 8 & $\begin{array}{l}\text { Docetaxel, Cisplatin, and } \\
5 \text {-FU }\end{array}$ & $50 \% \mathrm{CR}$ & Range: $19-88 \mathrm{M}$ & \begin{tabular}{|l}
1 YR OS \\
$62.5 \%$ \\
\end{tabular} \\
\hline
\end{tabular}

ORR $=$ objective response rate

$\mathrm{PFS}=$ progression free survival

OS $=$ overall survival

$\mathrm{NR}=$ not reported

$\mathrm{NA}=$ not applicable

$\mathrm{CR}=$ complete response 
retrospective studies suggested that there was no benefit in overall survival for surgical intervention in patients with metastatic SCCA [22]. Given the rising global incidence of anal carcinoma, it is likely more patients may be diagnosed with advanced disease. Furthermore, despite the use of anti-retroviral therapy in HIV+/AIDS patients, the incidence of anal carcinoma continues to rise [23]. Chemotherapeutic agents commonly utilized are those provided in other more common SCCA's: 5-fluorouracil (5-FU) and cisplatin, carboplatin, paclitaxel, and carboplatin and paclitaxel [24-29].

The purpose of this study was to evaluate treatment outcomes among patients receiving systemic chemotherapy followed by multidisciplinary management or palliative systemic chemotherapy for metastatic SCCA of the anal canal.

\section{RESULTS}

Seventy-seven patients met eligibility criteria for the purpose of this study. Baseline patient characteristics are described in Table 2 with subgroup demographics. All patients were evaluated for survival. The median age was 56 years. Only 7 patients (9\%) had a known history of chronic immunosuppression (HIV or hepatitis). Six patients $(8 \%)$ had a prior history of other sexually transmitted disease; 4 of those patients $(5 \%)$ had a known history of HPV. The majority were female patients (70\%). Fifty-two patients (67\%) had received prior chemoradiation therapy for curative intent for early stage disease. In these select patients, the median interval from diagnosis to the development of metastatic disease was 19 months.

The majority of tumor histology was moderate $(34 \%)$ or poorly differentiated $(51 \%)$. Frequent sites of metastatic disease included distant lymph nodes $(33 \%)$, pelvis $(31 \%)$, liver $(25 \%)$, lungs $(15 \%)$ and bone $(8 \%)$.

Forty-two patients (55\%) received 5-FU + cisplatin (PF); and twenty-four patients $(31 \%)$ received carboplatin + paclitaxel (CP) as first line treatment; other therapy was provided in 11 patients (14\%), (Table 3 ). Sixty-six patients $(86 \%)$ were evaluable for response for the two most common regimens of $\mathrm{PF}$ and $\mathrm{CP}$.

After a median follow-up of 42 months, the median PFS for all patients was 7 months after receipt of a median of 4 cycles. The median OS was 22 months as indicated in Figure 1; the median number of subsequent lines of chemotherapy received was 1 .

\section{Table 2: Patient Demographics}

\begin{tabular}{|l|l|}
\hline \multicolumn{2}{l}{ Total N=77 (\%) } \\
\hline Mean Age at Diagnosis of Metastatic Disease & $\mathbf{5 6}$ (Range: 37-82) \\
\hline Gender & \\
\hline Male & $23(30)$ \\
\hline Female & $54(70)$ \\
\hline Histologic Grade & \\
\hline Well & $1(1)$ \\
\hline Moderate & $26(34)$ \\
\hline Poor & $39(51)$ \\
\hline Unknown & $11(14)$ \\
\hline Prior Definitive Chemoradiation & \\
\hline No & $25(33)$ \\
\hline Yes & $52(67)$ \\
\hline Prior History of Viral Infection: & \\
\hline None & $60(78)$ \\
\hline HIV & $3(4)$ \\
\hline HPV & $4(5)$ \\
\hline Hepatitis B or C & $4(5)$ \\
\hline Other STD & $6(8)$ \\
\hline
\end{tabular}

$\mathrm{HIV}=$ human immunodeficiency virus

$\mathrm{HPV}=$ human papilloma virus

STD = sexually transmitted disease 
Table 3: Chemotherapy Regimens

\begin{tabular}{|c|c|c|}
\hline Regimen & $\mathrm{N}=77(\%)$ & Dosing Schedule \\
\hline 5-FU + Cisplatin (PF) & $42(55)$ & $\begin{array}{l}\text { 5-FU } 750 \mathrm{mg} / \mathrm{m} 2 / \text { day CI days } 1-5+ \\
\text { Cisplatin } 75 \mathrm{mg} / \mathrm{m} 2 \text { IV day } 1 \text {, q28 Days }\end{array}$ \\
\hline Carboplatin + Paclitaxel (CP) & $24(31)$ & $\begin{array}{l}\text { Carboplatin AUC of } 5 \text { IV day } 1+ \\
\text { Paclitaxel } 175 \mathrm{mg} / \mathrm{m} 2 \text { IV day } 1, \mathrm{q} 21 \text { Days }\end{array}$ \\
\hline Other & $11(14)$ & $\mathrm{N} / \mathrm{A}$ \\
\hline
\end{tabular}

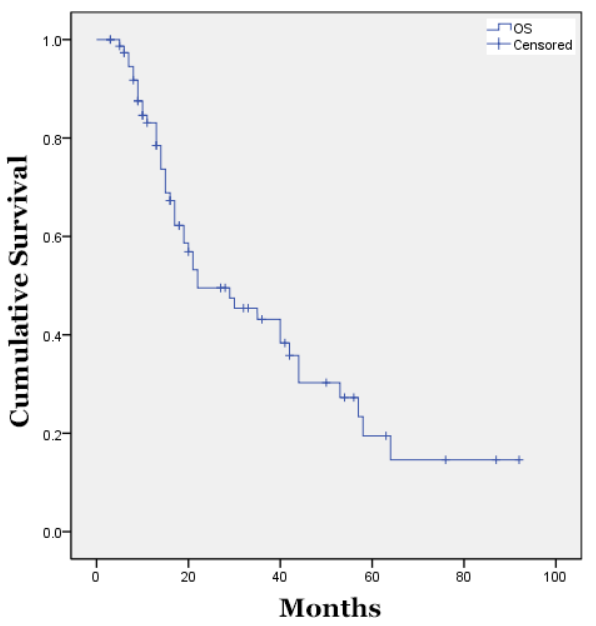

Figure 1: Median Overall Survival of All Treated Patients.

When stratified by most commonly provided chemotherapy regimens the observed median PFS was greater for PF vs. CP, 8 months $(95 \%$ CI: $4 \cdot 5-11 \cdot 5)$ vs. 4 months (95\% CI: $1 \cdot 7-6 \cdot 3)$, respectively, although this difference was not statistically significant. The response rate for the PF regimen also appeared more favorable (Table 4).

Among the 33 patients who underwent multidisciplinary management for their metastatic disease following systemic chemotherapy, 19 (58\%) underwent surgical resection of the metastatic site or RFA and 14 (42\%) underwent chemoradiation, (Table 5). Of those patients undergoing surgical intervention, recurrent metastatic disease was specifically noted in the inguinal and retroperitoneal lymph nodes $(\mathrm{N}=5,22 \%)$, pelvis $(\mathrm{N}=5,22 \%)$, lung $(\mathrm{N}=2,8 \%)$, and liver $(\mathrm{N}=11,48 \%)$. Surgical intervention was provided as indicated in Table 5. If concurrent chemoradiation therapy was provided, $\mathrm{PF}$ was commonly used as a radiation sensitizer in 50\% of patients. Subsequently, 4 of the 33 patients $(12 \%)$ developed recurrent disease and underwent repeat surgical intervention [liver resection $(\mathrm{N}=1)$; RFA of the liver $(\mathrm{N}=1)$, and lung resection $(\mathrm{N}=2)]$.

Of those patients who proceeded to receive multidisciplinary management for intent of cure, the median PFS was significantly longer at 16 months
(95\% CI: $9 \cdot 2-22 \cdot 8)$ compared to those patients receiving palliative systemic chemotherapy, with a PFS of only 5 months (95\% CI: $3 \cdot 5-6 \cdot 5), p<0 \cdot 001$. The difference in OS was also longer with a median OS of 53 months (95\% CI: $28 \cdot 3-77 \cdot 6$ ) compared to those undergoing palliative systemic chemotherapy, whose median OS was 17 months (95\% CI: $13 \cdot 9-20 \cdot 1), p<0 \cdot 001$ (Figure 2). When evaluating age, gender, race (white vs. non-white), only younger age was significant by univariate $(p=0.02)$ and multivariate analysis $(p=0 \cdot 04)$ for increased overall survival.

\section{DISCUSSION}

SCCA of the anal canal is viewed as an uncommon malignancy. Yet, the incidence continues to rise by $2 \%$ per year in the US and will impact greater than 27,000 individuals worldwide [30]. Little published data exists other than small case studies or case series, with minimal information for clinical derivation regarding optimal chemotherapy regimens or outcome due to the limited sample size. Here we present our experience in chemotherapy naïve patients who were deemed to be not amenable to salvage APR. The median age of our patient population was comparable to the general population 
Table 4: Best Response - 5-FU + Cisplatin vs. Carboplatin + Paclitaxel

\begin{tabular}{|l|l|}
\hline Regimen & N $=\mathbf{6 6}(\%)$ \\
\hline 5-FU + Cisplatin (PF) & $42(63)$ \\
\hline Stable Disease & $12(29)$ \\
\hline Partial Response & $24(57)$ \\
\hline Progressive Disease & $6(14)$ \\
\hline Carboplatin + Paclitaxel (CP) & $24(37)$ \\
\hline Stable Disease & $5(21)$ \\
\hline Partial Response & $8(33)$ \\
\hline Progressive Disease & $11(46)$ \\
\hline
\end{tabular}

Table 5: Types of Multidisciplinary Treatment Provided to Patients

\begin{tabular}{|l|l|l|}
\hline \multicolumn{2}{|c}{ N=33 (43\%) } \\
\hline \multirow{4}{*}{ Gender } & Male $=8(24 \%)$ & Female $=25(76 \%)$ \\
\hline \multirow{4}{*}{$\begin{array}{l}\text { Chemotments } \\
\text { During Radiation Therapy }\end{array}$} & Surgery & $19(58 \%)$ \\
\cline { 2 - 3 } & Chemoradiation & $14(42 \%)$ \\
\cline { 2 - 3 } & 5-FU + Cisplatin & $7(50 \%)$ \\
\cline { 2 - 3 } & 5-FU + Mitomycin C & $1(7 \%)$ \\
\cline { 2 - 3 } & Carboplatin + Paclitaxel & $2(14 \%)$ \\
\cline { 2 - 3 } & 5-FU or Capecitabine & $2(14 \%)$ \\
\cline { 2 - 3 } & None & $1(7 \%)$ \\
\hline \multirow{5}{*}{ Surgical Treatments Provided } & Liver Resection & $9(39 \%)$ \\
\cline { 2 - 3 } & Lung Resection & $2(9 \%)$ \\
\cline { 2 - 3 } & Lymph Node Dissection & $5(22 \%)$ \\
\cline { 2 - 3 } & Radical Pelvic Resection & $4(17 \%)$ \\
\cline { 2 - 3 } & Radiofrequency Ablation & $3(13 \%)$ \\
\cline { 2 - 3 } & Liver Resection & $9(39 \%)$ \\
\hline
\end{tabular}

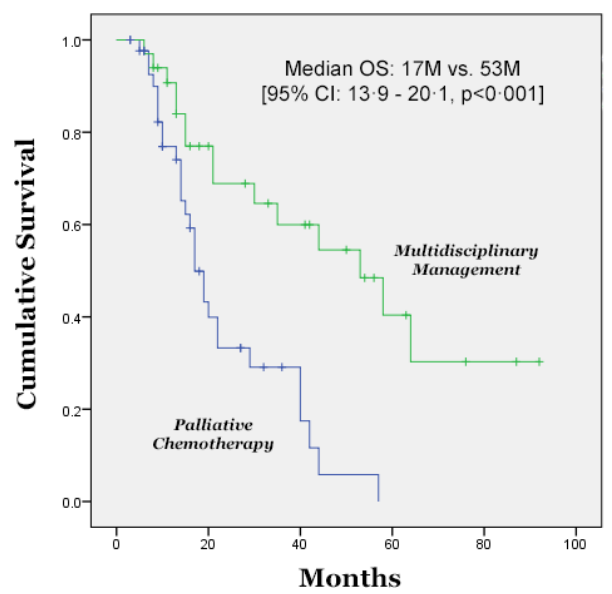

Figure 2: Median Overall Survival of Patients Treated with Multidisciplinary Intervention versus Palliative Systemic Chemotherapy. 
with a median age of 56 years old. We determined the median interval for the development of metastatic disease following treatment for locally advanced disease to be less than 2 years indicating the importance of close surveillance during this period. We were able to establish that the use of 5-FU + cisplatin or carboplatin + paclitaxel therapy provides a reasonable benefit in PFS of 7 months and an OS of 22 months. Furthermore, our findings demonstrate the potential benefit of multidisciplinary management in select patients with a further improvement of PFS to 16 months and median OS of 53 months.

To our knowledge, this is the largest study to describe treatment outcomes in patients diagnosed with metastatic SCCA of the anal canal. Prior to our analysis the choice of chemotherapy has been 5-FU + cisplatin despite the fact that there is "limited data" (www.ncen .org). Furthermore, the NCCN guidelines suggest there is "no evidence to support surgical intervention" in metastatic anal cancer patients. Any consideration of additional types of chemotherapy for these patients has largely been informally extrapolated from the treatment of more common metastatic squamous cell carcinomas such as head and neck, lung, and cervical carcinoma [24-29]. Our data as presented here provides information regarding the role of $5-\mathrm{FU}+$ cisplatin as well as carboplatin + paclitaxel. Here we also demonstrate the possible benefits of the utilization of a multidisciplinary approach when appropriate.

Our analysis is subject to several limitations. The data is retrospective and has been collected at a single institution which may result in an inherent treatment bias. 5-FU + cisplatin therapy was more commonly utilized overall and does not allow a direct comparison to carboplatin + paclitaxel. Carboplatin + paclitaxel was often chosen for palliation in unresectable patients likely as a result of the well-known potential treatment related toxicities associated with prolonged 5-FU + cisplatin therapy (e.g., nausea, vomiting, acute renal insufficiency, etc.). Due to the size of the study and retrospective nature of our analysis we were unable to differentiate a true difference between the two chemotherapy regimens for patients with unresectable disease. Chemotherapy dose intensity and dose delays also may not have been fully captured unless the treatment was provided directly at MDACC. The majority of patients were HIV- so the findings may not be generalizable to HIV+ patients.

We believe there are strengths to our analysis. A single institution analysis results in uniformity in care, permitting a more informative median PFS and OS evaluation than previously demonstrated in small case series. Furthermore, systemic chemotherapy supplemented by a multi-modality approach to optimize patient management provided patients an impressive median OS of 53 months which far exceeds previously reported median overall survival rates of 8-12 months in smaller case studies.
Though we are in the era of biologic agents or targeted therapies (i.e., bevacizumab, cetuximab, and panitumumab) the use of biologics was rarely provided in conjunction with chemotherapy $(\mathrm{N}=2)$ due to patient provider concerns for reimbursement and due to the lack of prospective data for this patient population. However, recent phase III data indicate that cetuximab has a role in unresectable head and neck carcinomas in conjunction with radiation therapy and also for locally advanced, surgically unresectable, non-small cell lung carcinoma for response and overall survival $[17,31,32]$. The role of cetuximab as a radiation sensitizer has been investigated in combination with chemotherapy with curative intent for locally advanced anal cancer in HIV+ and HIV- patients [33, 34]. Both studies have completed accrual; final results are pending.

It has been previously reported that detectable human papilloma virus (HPV) has a favorable prognosis in head and neck cancer for disease-free and overall survival $[35,36]$. A surrogate marker for HPV is p16, a cell cycle regulator [37]. The E7 oncoprotein of HPV may be inactivated by the retinoblastoma $(\mathrm{Rb})$ protein resulting in p16 overexpression which is a positive prognostic factor for disease-free survival and overall survival in oropharyngeal cancer $[38,39]$. We have recently evaluated the presence of the HPV positivity and its impact on prognosis in metastatic SCCA of the anal canal [40]. Our results suggest that $\mathrm{HPV}+$ tumors have improved OS relative to HPV- tumors. However, the majority of patients (95\%) were noted to have HPV+ tumors limiting our ability to adequately evaluate the HPV- tumor specimens. Post ad-hoc data from the phase III randomized SPECTRUM trial of PF $+/$ - panitumumab indicate that HPV positivity was associated with a survival benefit when combined with fully human monoclonal antibody, panitumumab, thereby indicating further analysis is warranted regarding HPV positivity and role of anti-EGFR therapy $[41,42]$.

It is presumed the incidence of anal carcinoma will continue to gradually increase over the next several years. Given the rising incidence of anal carcinoma, it is likely more patients will be diagnosed with advanced disease. Globally, HPV remains the most common sexually transmitted disease [43]. Despite the advent of antiretroviral therapy in $\mathrm{HIV}+$ patients and the increased life expectancy of the HIV patient population, the incidence of SCCA of the anal canal has not decreased $[44,45]$. Recent approval for the quadrivalent HPV vaccine was granted in the US for adolescent/teenage girls as well as sexually active woman up to 26 years of age for the prevention of cervical cancer [46, 47], yet its use has not been widely adopted in the US, and its role in the treatment of carcinoma of the anal canal is investigational. Given the current available data in the non-HIV and HIV+ patient population, it is clear further exploration of chemotherapy with or without the addition of biologic agents should be 
formally pursued for the metastatic anal carcinoma patient population.

With the support of the National Cancer Institute, the International Rare Cancer Initiative (IRCI) recognizes the global impact of anal carcinoma and the need to identify the most appropriate treatment regimen for metastatic SCCA of the anal canal. InterAACT (NCT02051868) is the first prospective randomized phase II study ever to be conducted in metastatic SCCA of the anal canal patients and will compare 5-FU + cisplatin versus carboplatin + paclitaxel. The trial is now open to enrollment [48]; HIV+ patients will be considered eligible. Tissue correlatives will be collected in InterAACT. With the successful completion of this study, it is the hope that biologic agents will be studied in the phase III setting.

\section{MATERIALS AND METHODS}

Patients with metastatic SCCA of the anal canal treated at MD Anderson Cancer Center (MDACC) between January 1, 2000 and May 1, 2012 were identified. All patients were required to be treatment naïve to systemic chemotherapy for metastatic disease but may have received prior definitive chemoradiation therapy for their locally advanced primary tumor. All patients were reviewed by the MDACC colorectal surgical oncology team and were determined to not be amenable to surgical salvage with an abdominal perineal resection (APR). All patients were recommended to proceed with systemic chemotherapy. Medical records were reviewed for patient demographics, tumor characteristics, and clinical outcomes including: progression-free survival (PFS), overall survival (OS), response rate (RR), prior history of sexually transmitted diseases (STDs) or immunosuppressed state (if documented), histology, chemotherapy regimen, subsequent lines of therapy, and treatment intervention. All patients were provided treatment recommendations by an MD Anderson physician but were allowed to receive their systemic chemotherapy at an outside institution for added convenience. All patients were required to have all radiographic imaging including a CT scan of the chest, and CT or MRI of the abdomen, and pelvis at our facility as well as follow up. If systemic treatment was provided at an outside institution, corresponding physician notes were utilized for verification of toxicity, and response to the recommended treatment regimen. If the patient had demonstrated partial response/stable disease from their systemic chemotherapy, the patient was referred for multidisciplinary treatment recommendations to either surgical oncology or radiation oncology for consultation.

For accuracy, we limited the sample to include only those patients who were initially evaluated with treatment recommendations provided at MDACC plus at least 1 follow-up visit with a physician or a mid-level provider with restaging diagnostic imaging completed at MDACC. Patients with prior or concurrent malignancies within 5 years of diagnosis, except squamous or basal cell skin carcinomas, were excluded.

Two treatment categories were created: 1) Palliative systemic chemotherapy was defined for all patients with diffuse metastatic disease not amenable to surgical or radiation oncology intervention, or 2) Multidisciplinary management inclusive of those patients that had received systemic chemotherapy but who were determined by the multidisciplinary team to potentially benefit from treatment intervention (e.g., surgery, stereotactic radiation therapy, radiofrequency ablation, etc.).

OS was defined as date of diagnosis of metastatic disease until date of death or last follow-up. PFS was defined as date of initiation of therapy until date of documented progression. Follow-up was performed by review of clinic notes and contact with corresponding outside oncologist. Death and overall survival were also determined by use of the social security death index (SSDI) search, which was corroborated with institutional medical records and the tumor registry of MDACC. The distribution of each continuous variable was summarized by its mean, standard deviation and range. The distribution of each categorical variable was summarized in terms of its frequencies and percentages. Log rank tests were used to compare each time-to-event variable (OS and PFS) between groups using the Kaplan-Meier method. This analysis was approved by the institutional review board at MDACC and a waiver of consent was granted.

\section{CONCLUSIONS}

To date, there is no established prospectively evaluated chemotherapy algorithm for metastatic squamous cell carcinoma of the anal canal. Based on our findings, 5-FU + cisplatin or carboplatin + paclitaxel regimens have activity in the treatment of metastatic SCCA of the anal canal warranting further analysis. More importantly, multidisciplinary management (e.g., surgical resection, RFA, stereotactic radiation therapy, etc.) should be considered for select patients whenever appropriate to improve their overall outcomes.

\section{ACKNOWLEDGEMENTS}

Support for this study was provided by an anonymous philanthropic donor, the Farrah Fawcett Foundation, and the E.B. Anal Cancer Foundation.

With special thanks to Amir Mehdizadeh for assistance with final editing.

\section{Disclosure}

The authors disclose no conflicts of interest. 


\section{REFERENCES}

1. Siegel R, Naishadham D, Jemal A. Cancer statistics, 2014. CA Cancer J Clin. 2014; 64:9-29.

2. Boman BM, Moertel CG, O'Connell MJ, Scott M, Weiland LH, Beart RW, Gunderson LL, Spencer RJ. Carcinoma of the anal canal. A clinical and pathologic study of 188 cases. Cancer. 1984; 54:114-125.

3. Eng C, Abbruzzese J, Minsky BD. Chemotherapy and radiation of anal canal cancer: the first approach. Surg Oncol Clin N Am. 2004; 13:309-320, viii.

4. Gunderson LL, Winter KA, Ajani JA, Pedersen JE, Moughan J, Benson AB, Thomas CR, Mayer RJ, Haddock MG, Rich TA, Willett CG. Long-term update of US GI intergroup RTOG 98-11 phase III trial for anal carcinoma: survival, relapse, and colostomy failure with concurrent chemoradiation involving fluorouracil/mitomycin versus fluorouracil/cisplatin. J Clin Oncol. 2012; 30:4344-4351.

5. Sebag-Montefiore D, James R, Meadows H, Begum R, Cunningham D, Northover J, Ledermann J. The pattern and timing of disease recurrence in squamous cancer of the anus: Mature results from the NCRI ACT II trial. J Clin Oncol. 2012; 30.

6. Eng C, Xing Y, You YN, Chang GJ, Das P, Phillips J, Wolff RA, Rodriguez-Bigas MA, Ohinata A, Crane CH. Cisplatin (C) based chemoradiation (CXRT) for locally advanced squamous cell carcinoma (SCCA) of the anal canal (AC): A 20-year perspective. J Clin Oncol. 2011; 29.

7. Eng C, Pathak P. Treatment options in metastatic squamous cell carcinoma of the anal canal. Curr Treat Options Oncol. 2008; 9:400-407.

8. Alcindor T. Activity of paclitaxel in metastatic squamous anal carcinoma. Int J Colorectal Dis. 2008; 23:717.

9. Jhawer M, Mani S, Lefkopoulou M, Hahn RG, Harris J, Catalano PJ, Haller D. Phase II study of mitomycin-C, adriamycin, cisplatin (MAP) and bleomycin-CCNU in patients with advanced cancer of the anal canal: an eastern cooperative oncology group study E7282. Invest New Drugs. 2006; 24:447-454.

10. Abbas A, Nehme E, Fakih M. Single-agent paclitaxel in advanced anal cancer after failure of cisplatin and 5-fluorouracil chemotherapy. Anticancer Res. 2011; 31:4637-4640.

11. Ajani JA, Winter KA, Gunderson LL, Pedersen J, Benson AB, Thomas CR, Mayer RJ, Haddock MG, Rich TA, Willett C. Fluorouracil, mitomycin, and radiotherapy vs fluorouracil, cisplatin, and radiotherapy for carcinoma of the anal canal: a randomized controlled trial. JAMA. 2008; 299:1914-1921.

12. Bartelink H, Roelofsen F, Eschwege F, Rougier P, Bosset JF, Gonzalez DG, Peiffert D, van Glabbeke M, Pierart M. Concomitant radiotherapy and chemotherapy is superior to radiotherapy alone in the treatment of locally advanced anal cancer: results of a phase III randomized trial of the European Organization for Research and Treatment of Cancer Radiotherapy and Gastrointestinal Cooperative Groups. J Clin Oncol. 1997; 15:2040-2049.

13. Meropol NJ, Niedzwiecki D, Shank B, Colacchio TA, Ellerton J, Valone F, Budinger S, Day JM, Hopkins J, Tepper J, Goldberg RM, Mayer RJ. Induction therapy for poor-prognosis anal canal carcinoma: a phase II study of the cancer and Leukemia Group B (CALGB 9281). J Clin Oncol. 2008; 26:3229-3234.

14. Jaiyesimi IA, Pazdur R. Cisplatin and 5-fluorouracil as salvage therapy for recurrent metastatic squamous cell carcinoma of the anal canal. Am J Clin Oncol. 1993; 16:536-540.

15. Hainsworth JD, Burris HA, Meluch AA, Baker MN, Morrissey LH, Greco FA. Paclitaxel, carboplatin, and longterm continuous infusion of 5-fluorouracil in the treatment of advanced squamous and other selected carcinomas: results of a Phase II trial. Cancer. 2001; 92:642-649.

16. Evans TR, Mansi JL, Glees JP. Response of metastatic anal carcinoma to single agent carboplatin. Clin Oncol (R Coll Radiol). 1993; 5:57-58.

17. Bonner JA, Harari PM, Giralt J, Cohen RB, Jones CU, Sur RK, Raben D, Baselga J, Spencer SA, Zhu J, Youssoufian H, Rowinsky EK, Ang KK. Radiotherapy plus cetuximab for locoregionally advanced head and neck cancer: 5-year survival data from a phase 3 randomised trial, and relation between cetuximab-induced rash and survival. Lancet Oncol. 2010; 11:21-28.

18. Wilking N, Petrelli N, Herrera L, Mittelman A. Phase II study of combination bleomycin, vincristine and high-dose methotrexate (BOM) with leucovorin rescue in advanced squamous cell carcinoma of the anal canal. Cancer Chemother Pharmacol. 1985; 15:300-302.

19. Ajani JA, Carrasco CH, Jackson DE, Wallace S. Combination of cisplatin plus fluoropyrimidine chemotherapy effective against liver metastases from carcinoma of the anal canal. Am J Med. 1989; 87:221-224.

20. Faivre C, Rougier P, Ducreux M, Mitry E, Lusinchi A, Lasser P, Elias D, Eschwege F. 5-Fluorouracile and cisplatinum combination chemotherapy for metastatic squamous-cell anal cancer. Bull Cancer. 1999; 86:861-865.

21. Kim S, Jary M, Mansi L, Benzidane B, Cazorla A, Demarchi M, Nguyen T, Kaliski A, Delabrousse E, Bonnetain F, Letondal P, Bosset JF, Valmary-Degano S, Borg C. DCF (docetaxel, cisplatin and 5-fluorouracil) chemotherapy is a promising treatment for recurrent advanced squamous cell anal carcinoma. Ann Oncol. 2013; 24:3045-3050.

22. Pawlik TM, Gleisner AL, Bauer TW, Adams RB, Reddy SK, Clary BM, Martin RC, Scoggins CR, Tanabe KK, Michaelson JS, Kooby DA, Staley CA, Schulick RD, Vauthey JN, Abdalla EK, Curley SA. Liverdirected surgery for metastatic squamous cell carcinoma to 
the liver: results of a multi-center analysis. Ann Surg Oncol. 2007; 14:2807-2816.

23. Shiels MS, Pfeiffer RM, Gail MH, Hall HI, Li J, Chaturvedi AK, Bhatia K, Uldrick TS, Yarchoan R, Goedert JJ, Engels EA. Cancer Burden in the HIV-Infected Population in the United States. JNCI. 2011; 103:753-762.

24. Fountzilas G, Skarlos D, Athanassiades A, KalogeraFountzila A, Samantas E, Bacoyiannis C, Nicolaou A, Dombros N, Briasoulis E, Dinopoulou M, Stathopoulos G, Pavlidis N, Kosmidis P, Daniilidis J. Paclitaxel by three-hour infusion and carboplatin in advanced carcinoma of nasopharynx and other sites of the head and neck. A phase II study conducted by the Hellenic Cooperative Oncology Group. Ann Oncol. 1997; 8:451-455.

25. Kelly K, Crowley J, Bunn Jr. PA, Presant CA, Grevstad PK, Moinpour CM, Ramsey SD, Wozniak AJ, Weiss GR, Moore DF, Israel VK, Livingston RB, Gandara DR. Randomized phase III trial of paclitaxel plus carboplatin versus vinorelbine plus cisplatin in the treatment of patients with advanced non-small-cell lung cancer: a Southwest Oncology Group trial. J Clin Oncol. 2001; 19:3210-3218.

26. Gibson MK, Li Y, Murphy B, Hussain MHA, DeConti RC, Ensley J, Forastiere AA. Randomized Phase III Evaluation of Cisplatin Plus Fluorouracil Versus Cisplatin Plus Paclitaxel in Advanced Head and Neck Cancer (E1395): An Intergroup Trial of the Eastern Cooperative Oncology Group. J Clin Oncol. 2005; 23:3562-3567.

27. Long III HJ, Bundy BN, Grendys Jr EC, Benda JA, McMeekin DS, Sorosky J, Miller DS, Eaton LA, Fiorica JV. Randomized Phase III Trial of Cisplatin With or Without Topotecan in Carcinoma of the Uterine Cervix: A Gynecologic Oncology Group Study. J Clin Oncol. 2005; 23:4626-4633.

28. Kaern J, Trope C, Sundfoer K, Kristensen GB. Cisplatin/ 5-fluorouracil treatment of recurrent cervical carcinoma: a phase II study with long-term follow-up. Gynecol Oncol. 1996; 60:387-392.

29. Green JA, Lainakis G. Cytotoxic chemotherapy for advanced or recurrent cervical cancer. Ann Oncol. 2006; 17:230-232.

30. National Cancer Institute: $\mathrm{PDQ}^{\circledR}$ Anal Cancer Prevention. Bethesda, MD: National Cancer Institute. Date last modified 09/19/2014. Available at: http://cancer.gov/cancertopics/pdq/ prevention/anal/HealthProfessional. Accessed 02/21/2014.

31. Bonner JA, Harari PM, Giralt J, Azarnia N, Shin DM, Cohen RB, Jones CU, Sur R, Raben D, Jassem J, Ove R, Kies MS, Baselga J, Youssoufian H, Amellal N, Rowinsky EK, et al. Radiotherapy plus cetuximab for squamous-cell carcinoma of the head and neck. N Engl J Med. 2006; 354:567-578.

32. Lynch TJ, Patel T, Dreisbach L, McCleod M, Heim WJ, Hermann RC, Paschold E, Iannotti NO, Dakhil S, Gorton S, Pautret V, Weber MR, Woytowitz D. Cetuximab and first-line taxane/carboplatin chemotherapy in advanced non-small-cell lung cancer: results of the randomized multicenter phase III trial BMS099. J Clin Oncol. 2010; 28:911-917.

33. http://clinicaltrials.gov/show/NCT00324415. (2013). Cisplatin, Fluorouracil, Cetuximab, and Radiation Therapy in Treating Patients With HIV and Stage I, Stage II, or Stage III Anal Cancer.

34. Clinicaltrials.gov. (2013). NCT00316888: Cetuximab, Cisplatin, Fluorouracil, and Radiation Therapy in Treating Patients With Stage I, Stage II, or Stage III Anal Cancer.

35. Attner P, Du J, Nasman A, Hammarstedt L, Ramqvist T, Lindholm J, Marklund L, Dalianis T, Munck-Wikland E. Human papillomavirus and survival in patients with base of tongue cancer. Int J Cancer. 2011; 128:2892-2897.

36. Ang KK, Harris J, Wheeler R, Weber R, Rosenthal DI, Nguyen-Tan PF, Westra WH, Chung $\mathrm{CH}$, Jordan RC, Lu C, Kim H, Axelrod R, Silverman CC, Redmond KP, Gillison ML. Human papillomavirus and survival of patients with oropharyngeal cancer. N Engl J Med. 2010; 363:24-35.

37. Ajani JA, Wang X, Izzo JG, Crane CH, Eng C, Skibber JM, Das P, Rashid A. Molecular biomarkers correlate with disease-free survival in patients with anal canal carcinoma treated with chemoradiation. Dig Dis Sci. 2010; 55:1098-1105.

38. Rischin D, Young RJ, Fisher R, Fox SB, Le QT, Peters LJ, Solomon B, Choi J, O’Sullivan B, Kenny LM, McArthur GA. Prognostic Significance of p16INK4A and Human Papillomavirus in Patients With Oropharyngeal Cancer Treated on TROG 02.02 Phase III Trial. J Clin Oncol. 2010; 28:4142-4148.

39. Fischer CA, Kampmann M, Zlobec I, Green E, Tornillo L, Lugli A, Wolfensberger M, Terracciano LM. p16 expression in oropharyngeal cancer: its impact on staging and prognosis compared with the conventional clinical staging parameters. Ann Oncol. 2010; 21:1961-1966.

40. Morris VK, Rashid A, Rodriguez-Bigas MA, Das P, Wolff RA, Chang GJ, Crane CH, Phillips J, Ohinata A, Rogers J, Eng C. Human Papillomavirus is Associated with Unique Clinicopathologic Features in Patients with Metastatic Squamous Cell Carcinoma of the Anal Canal. J Clin Oncol. 2014; 32.

41. Vermorken JB, Psyrri A, Mesia R, Peyrade F, Beier F, de Blas B, Celik I, Licitra L. Impact of tumor HPV status on outcome in patients with recurrent and/or metastatic squamous cell carcinoma of the head and neck receiving chemotherapy with or without cetuximab: retrospective analysis of the phase III EXTREME trial. Ann Oncol. 2014; 25:801-807.

42. Vermorken JB, Mesia R, Rivera F, Remenar E, Kawecki A, Rottey S, Erfan J, Zabolotnyy D, Kienzer HR, Cupissol D, Peyrade F, Benasso M, Vynnychenko I, De Raucourt D, Bokemeyer C, Schueler A, et al. Platinum-Based Chemotherapy plus Cetuximab in Head and Neck Cancer. N Engl J Med. 2008; 359:1116-1127. 
43. Forman D, de Martel C, Lacey CJ, Soerjomataram I, LortetTieulent J, Bruni L, Vignat J, Ferlay J, Bray F, Plummer M, Franceschi S. Global burden of human papillomavirus and related diseases. Vaccine. 2012; 30:F12-23.

44. Crum-Cianflone NF, Hullsiek KH, Marconi VC, Ganesan A, Weintrob A, Barthel RV, Agan BK. Anal cancers among HIV-infected persons: HAART is not slowing rising incidence. AIDS. 2009; 24:535-543.

45. Shiels MS, Cole SR, Kirk GD, Poole C. A meta-analysis of the incidence of non-AIDS cancers in HIV-infected individuals. J Acquir Immune Defic Syndr. 2009; 52:611-622.

46. Brown DR, Kjaer SK, Sigurdsson K, Iversen OE, Hernandez-Avila M, Wheeler CM, Perez G, Koutsky LA, Tay EH, Garcia P, Ault KA, Garland SM, Leodolter S, Olsson SE, Tang GW, Ferris DG, et al. The impact of quadrivalent human papillomavirus (HPV; types 6, 11,
16, and 18) L1 virus-like particle vaccine on infection and disease due to oncogenic nonvaccine HPV types in generally HPV-naive women aged 16-26 years. J Infect Dis. 2009; 199:926-935.

47. Paavonen J, Jenkins D, Bosch FX, Naud P, Salmeron J, Wheeler CM, Chow SN, Apter DL, Kitchener HC, Castellsague X, de Carvalho NS, Skinner SR, Harper DM, Hedrick JA, Jaisamrarn U, Limson GA, et al. Efficacy of a prophylactic adjuvanted bivalent L1 virus-like-particle vaccine against infection with human papillomavirus types 16 and 18 in young women: an interim analysis of a phase III double-blind, randomised controlled trial. Lancet. 2007; 369:2161-2170.

48. Clinicaltrials.gov. (2014). International Multicentre Study in Advanced Anal Cancer Comparing Cisplatin Plus 5 FU vs Carboplatin Plus Weekly Paclitaxel (InterAACT). 